Article

\title{
The influence of welding heat input on the quality and properties of high strength low-alloy dissimilar steel butt joints
}

\author{
Jacek Tomków $\mathbf{w}^{1, *}$ (D), Jacek Haras ${ }^{1}$ \\ 1 Gdańsk University of Technology, Poland \\ Jacek Haras, Ph.D.; jacek.haras@pg.edu.pl \\ * Correspondence: Jacek Tomków, Ph.D.; jacek.tomkow@pg.edu.pl
}

Received: 23.12.2019; Accepted: 25.02.2020

\begin{abstract}
The paper presents the results of non-destructive and destructive tests of dissimilar highstrength low-alloy S460ML and S460N steel butt joints. These steels are characterized by similar mechanical properties, but their carbon equivalent Ceriw values are much different. The joints were made using different values of heat input for each welding bead. They were tested by non-destructive methods: visual, penetrant, radiographic and ultrasonic tests. Then, the destructive tests were made: static tensile test, bending test, impact test and Vickers HV10 hardness measurements. The results of prepared examinations showed, that welding with higher heat input has significant impact on the mechanical properties of the dissimilar steel joints - the joint welded with bigger heat input was characterized by better mechanical properties.
\end{abstract}

Keywords: high-strength low-alloy steel; MAG welding; non-destructive testing; destructive testing; heat input

\section{Introduction}

The share of high-strength low-alloy steels as materials used in industry increases year by year. This is due to the fact that requirements are increasing for structures. This is associated with the need to reduce their weight while maintaining sufficiently high mechanical properties. These materials are widely

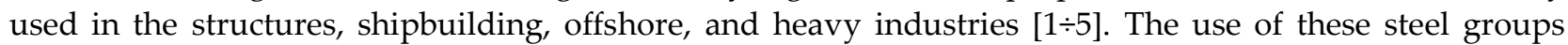
would be impossible without using joining processes. Common welding methods include manual metal arc (MMA) [6], metal active gas (MAG) [7], and self-shielding wire welding [8]. In addition, laser [9], hybrid [10], and friction welding techniques [11] are being developed.

The development of high-strength steel results in the need for weldability tests and the development of joint fabrication technologies that ensure their highest quality. A big problem when joining steels with

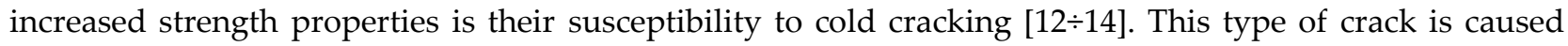
by the simultaneous occurrence of three factors $[15,16]$ :

- high diffusible hydrogen content in the deposited metal;

- brittle structures in the heat affected zone (HAZ);

- residual stresses after the welding process.

By eliminating one of these factors, it is possible to avoid the presence of cold cracks in welded joints. The methods that reduce the tendency to these cracks are $[17 \div 19]$ :

- increasing the value of heat input;

- pre-heating materials prior to welding;

- welding with additional materials to obtain plastic (austenitic) weld metal;

- appropriate bevelling of the sheets, reducing the stress value;

- heat treatment of the joint after welding.

Currently, tests of joints made of high-strength steel welded by the MAG method are widely conducted

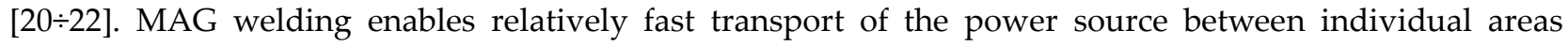
in which the welding process will be carried out. This enables welding of large constructions, which often require joining in the field.

The subject of the study was to assess the impact of the amount of heat input on the quality and properties of dissimilar joints of steel with increased strength during MAG welding. S460ML and S460N high-strength low-alloy steels were selected for research, which are widely used for offshore structures as well as elements of building. The development of the aforementioned constructions requires determining 
the conditions of joining these two materials so as to maintain the best quality of joints, while achieving optimal mechanical properties.

\section{Materials and methods \\ Materials used}

Sheets made of S460ML and S460N steel with dimensions of 350x150x12 mm were selected for testing. Before welding the dissimilar joints, the chemical composition of the delivered materials was tested, and they were carried out using the method of emission spectrometry with spark excitation. Manganese silicon electrode wire without copper coating G 464 M21 4Si1 according to EN ISO 14341-A was chosen as a filler material, which ensures sufficiently high weld metal strength. Welding tests were carried out in an M21 gas mixture shield ( $\mathrm{Ar} 80 \%+\mathrm{CO}_{2} 20 \%$ ). Table I presents the chemical composition of the materials used, while table II presents their properties in accordance with material approvals.

Table I. The chemical composition of used materials, wt \%

\begin{tabular}{cccccccccccc}
\hline Material & C & Si & Mn & P & S & Cr & Mo & Ni & Cu & V & CeIIw $^{*}$ \\
\hline S460ML $^{1}$ & 0.12 & 0.50 & 1.40 & 0.015 & 0.004 & 0.04 & 0.01 & 0.02 & 0.01 & 0.01 & 0.365 \\
S460N $^{1}$ & 0.16 & 0.53 & 1.51 & 0.020 & - & 0.07 & 0.03 & 0.05 & 0.13 & 0.097 & 0.464 \\
G 46 4 M21 4Si1 $^{2}$ & 0.074 & 0.95 & 1.68 & - & - & - & - & - & - & - & - \\
\hline
\end{tabular}

${ }_{1}^{1}$ in accordance with the analysis, ${ }^{2}$ in accordance with the manufacturer's data, ${ }^{*}$ carbon equivalent value according with International Institute of Welding

Table II. The mechanical properties of used materials, in accordance with manufacturer datas

\begin{tabular}{cccc}
\hline Material & Re [MPa] & Rm [MPa] & A [\%] \\
\hline S460ML & 515 & 598 & 25.0 \\
S460N & 511 & 626 & 27.3 \\
G 46 4 M21 4Si1 & $490 \mathrm{~min}$. & $590 \mathrm{~min}$. & $29.0 \mathrm{~min}$. \\
\hline
\end{tabular}

\section{Welding of the samples}

Two butt joints were made for the tests, which consisted of five beads. Specimens were welded by automated MAG method in a M21 gas mixture shield with a capacity of $15 \mathrm{l} / \mathrm{min}$. Both samples were welded using run-on and run-off plates. The first joint was made using higher heat input than the second joint.

The scheme of preparation of test joints and the method of beading are presented in figure 1, while welding parameters are given in table III.

Table III. Welding parameters

\begin{tabular}{cccccc}
\hline $\begin{array}{c}\text { Specimen } \\
\text { No. }\end{array}$ & Bead No. & I [A] & U [V] & Vsp [mm/min] & ql [kJ/mm] \\
\hline & 1 & 156 & 18.8 & 48.5 & 0.32 \\
1 & 2 & 166 & 18.8 & 46.0 & 0.50 \\
& 3 & 211 & 20.5 & 40.0 & 0.73 \\
& 4 & 210 & 20.5 & 35.0 & 0.99 \\
& 5 & 201 & 20.5 & 35.0 & 1.40 \\
& 1 & 140 & 20.0 & 34.2 & 0.39 \\
2 & 3 & 143 & 22.4 & 31.3 & 0.49 \\
& 4 & 149 & 22.7 & 24.5 & 0.66 \\
& 5 & 136 & 21.1 & 42.4 & 0.34 \\
& 5 & 153 & 22.7 & 26.2 & 0.63 \\
\hline
\end{tabular}

During the process, it was noticed that when the sample was made using higher heat input, the welding arc was burning more stable. 


\section{Research Procedure}

First, non-destructive testing: visual tests (VT) according to the recommendations of EN ISO 17637: 2017 was performed. Then: penetrant tests (PT) according to EN ISO 3452-1: 2013, radiographic tests according to EN ISO 17636-2: 2013 and ultrasonic tests using the Phased Array method according to EN ISO 19285: 2017. After non-destructive tests, joints were cut for destructive tests. The cutting scheme of joints is presented in figure 2 .

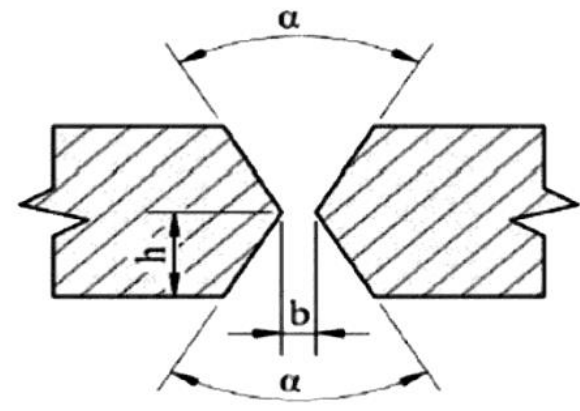

$b=1,5-2 \mathrm{~mm}, \alpha=60^{\circ} ; \mathrm{h}=6 \mathrm{~mm}$

(a)

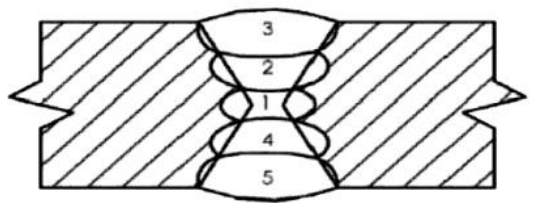

(b)

Fig. 1. The schematic view of the testing joint: a) The way of bevel cutting; b) The distribution of welding beads

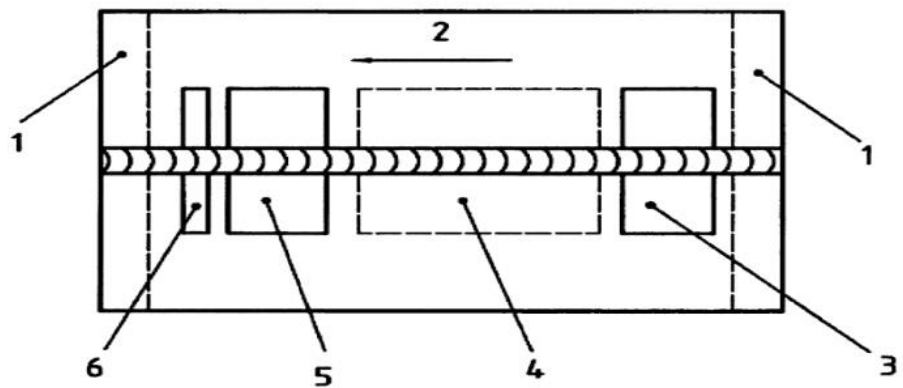

Fig. 2. The schematic view of specimens cutting for destructive tests: 1 - discard, 2 - welding direction, 3 and 5 - area for one tensile test specimen and bend specimen, 4 - area for impact test, 6 - area for hardness measurement specimens

After preparation of the samples, destructive tests were performed: static tensile test in accordance with EN ISO 6892-1: 2016-09, bending test in accordance with EN ISO 5173: 2010, impact tests using Charpy's hammer in accordance with EN ISO 148-1: 2017 and hardness measurements using Vickers in accordance with EN ISO 6507-1: 2018.

\section{Research results}

\section{Visual testing}

Visual tests were carried out 72 hours after the end of the welding process so as to ensure adequate time for the appearance of potential cold cracks, since both tested steels are characterized by high susceptibility to cold cracking [23,24].

The tests were performed in whole joint area, on both sides. During the VT tests of both joints, a small amount of spatter was found. In the case of a welded specimen using higher heat input, $20 \mathrm{~mm}$ long undercut was located in the central part of the joint from the $S 460 \mathrm{~N}$ steel side. During the examination of the second sample, two locations potential lack of fusion on the S460ML steel side, 15 and $10 \mathrm{~mm}$ long, were found. For both samples tested, non-compliances were detected from the face of the samples tested. Figure 3 presents the results of VT tests.

\section{Penetrant testing}

Before applying the penetrant, the surfaces were cleaned and the spatters were removed from them. A penetrant was then applied, the excess of which was removed with a cleaner after ten minutes, to then apply a developer layer. During the examination of the first sample, two indications appeared on both sides of the weld at the fusion line and a cluster of blisters at the place indicated during VT tests from the $S 460 \mathrm{~N}$ steel side. Examination of a sample welded with lower heat input showed no other indications than in VT tests. The results of PT testing are presented in figure 4. 


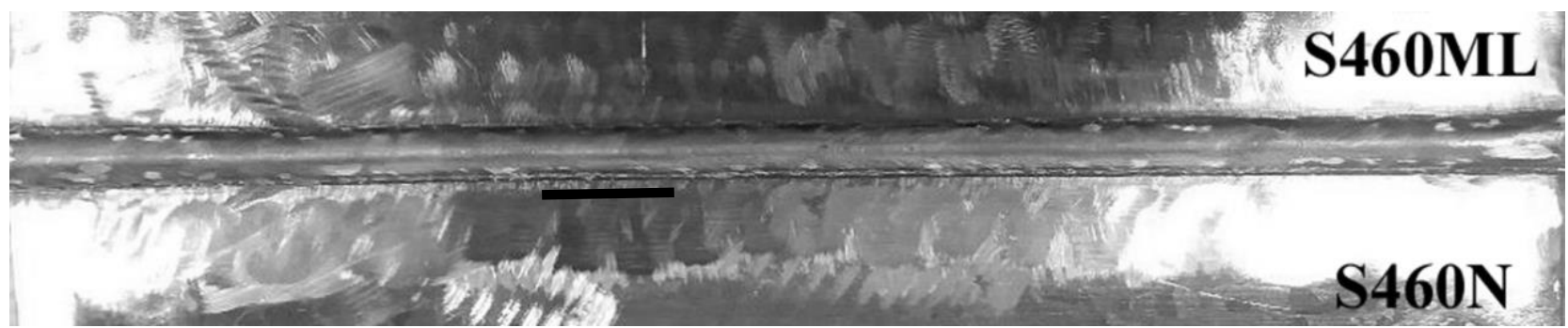

(a)

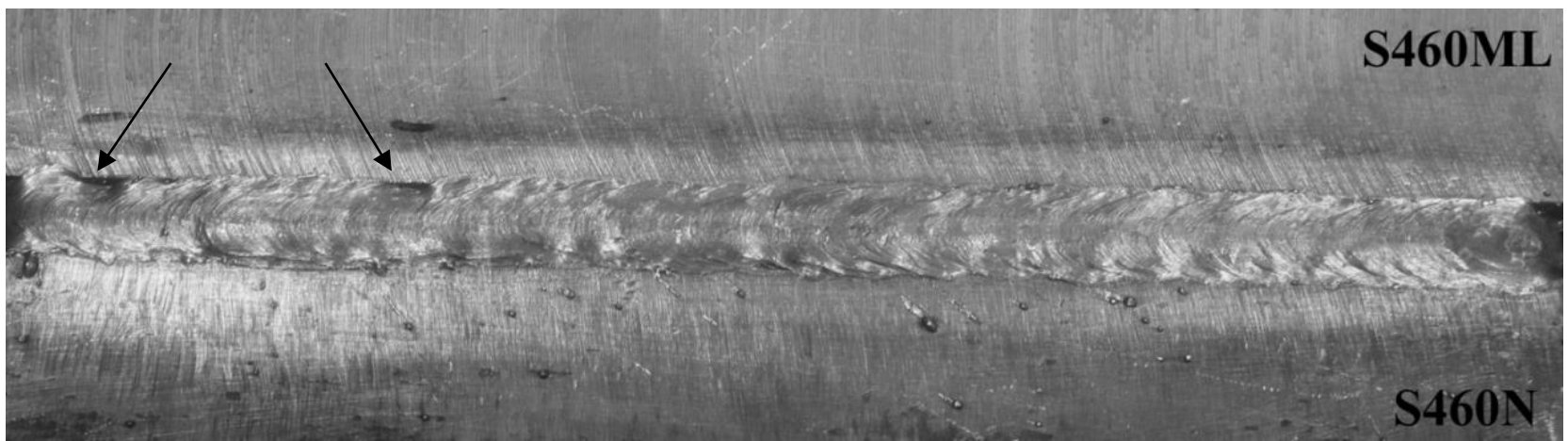

(b)

Fig. 3. The results of VT: a) Specimen 1, undercut marked by line; b) Specimen 2, lack of fusion marked by arrows

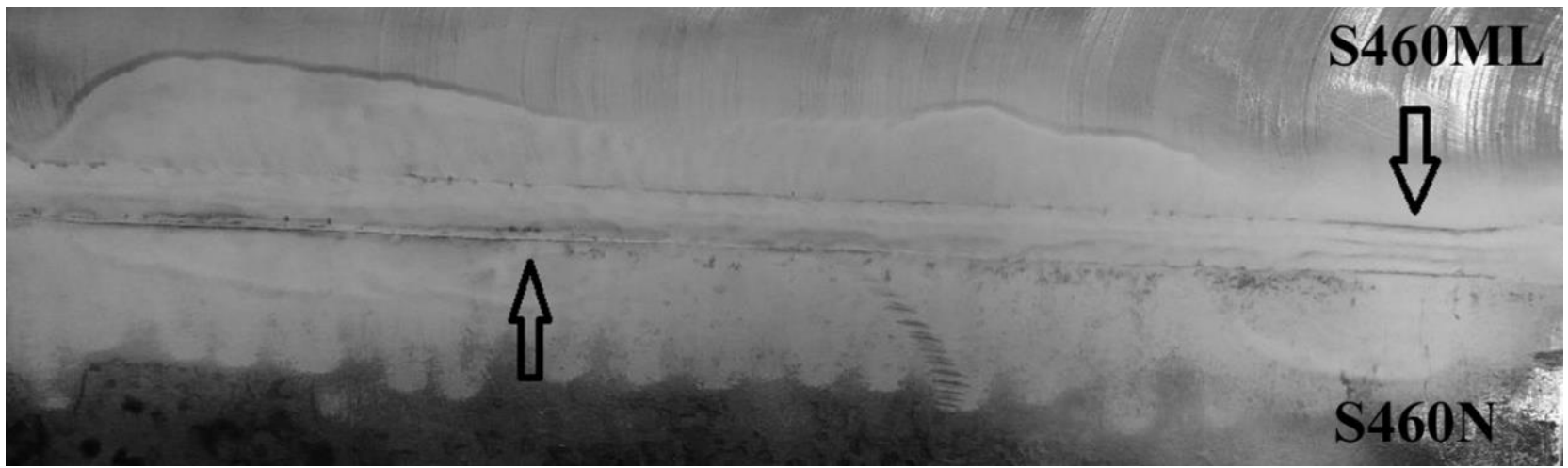

(a)

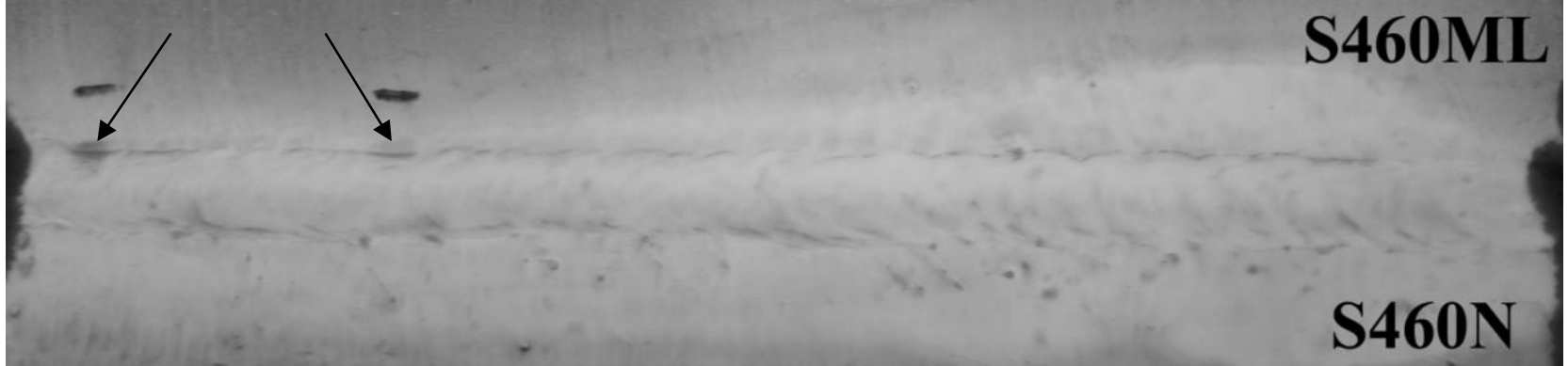

(b)

Fig. 4. Results of PT: a) Specimen 1, porosity in the middle, indication at right; b) Specimen 2, lack of fusion marked by lines

\section{Radiographic testing}

The ANDREX 300kV x-ray apparatus was used to perform the RT tests. Optimal exposure parameters were selected after preliminary tests:

- focal length: $700 \mathrm{~mm}$,

- exposure time: 5 min $30 \mathrm{~s}$,

- voltage: $185 \mathrm{kV}$,

- anode current intensity: $4.5 \mathrm{~mA}$. 
RT tests revealed the presence of non-conformities that were not disclosed during previous nondestructive testing. In the case of joint \#1, the presence of incomplete fusion was detected inside the material from the $5460 \mathrm{~N}$ steel side, which is located on the left side of the joint for a length of approx. 100 $\mathrm{mm}$. Incomplete fusion was also detected in the joint welded with less heat input. The incomplete fusion was on both the S460N steel side as in the previous case and the S460ML steel side. The total length of noncompliance was $180 \mathrm{~mm}$. No other imperfections were observed for both joints. The results of RT tests are presented in figure 5.

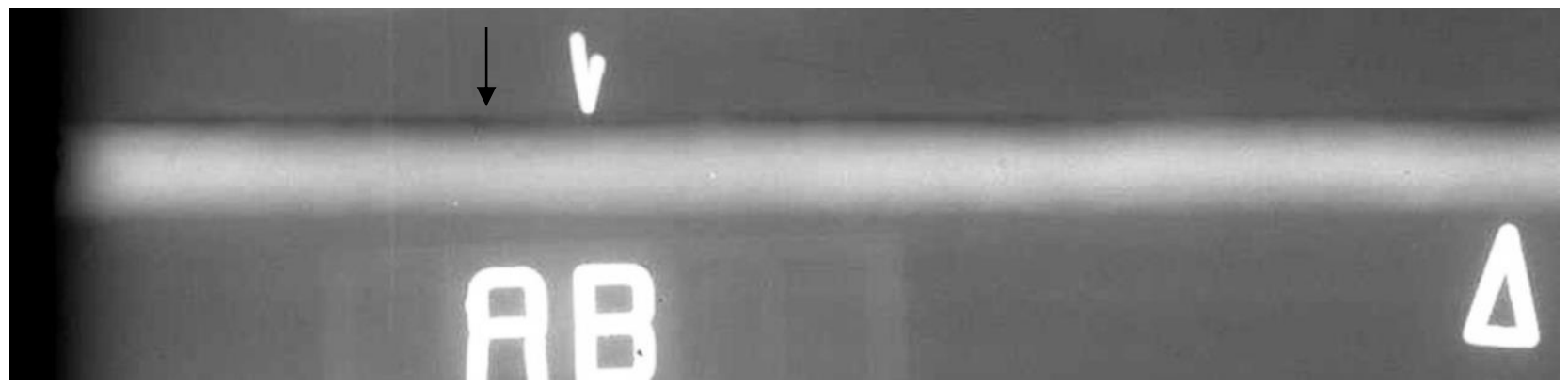

(a)

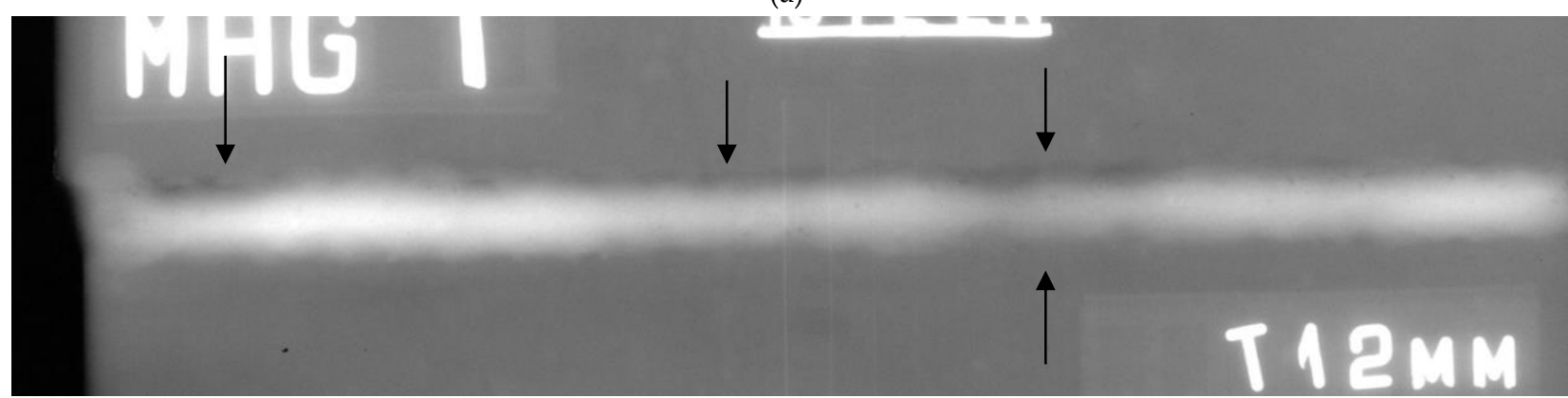

(b)

Fig. 5. Results of RT: a) Specimen 1; b) Specimen 2. Welding imperfections marked by arrows

\section{Ultrasonic testing}

The Phasor XS defector was used to perform the ultrasonic tests, allowing the use of the Phased Array head. A 16-element head was used, the wedge of which has a $36^{\circ}$ angle of inclination. The head sends $4 \mathrm{MHz}$ waves. During the tests, type A and S imaging were obtained. For both joints, the tests were carried out in places where indications on radiographs appeared so as to determine their depth of occurrence. Similarly to other non-destructive tests, it was proved that a greater number of discrepancies occurred in joint 2, which was performed using a smaller amount of introduced heat. It was also confirmed that discrepancies occur at the fusion line and in the HAZ of S460N steel. In the case of the first joint, discrepancies occurred at a depth of 8 to $11.5 \mathrm{~mm}$ from the upper surface of the sample, while in joint 2 their depth was more diverse, from 5 to $12 \mathrm{~mm}$. Examples of type A and $S$ flaw detectors imaging are presented in figure 6.

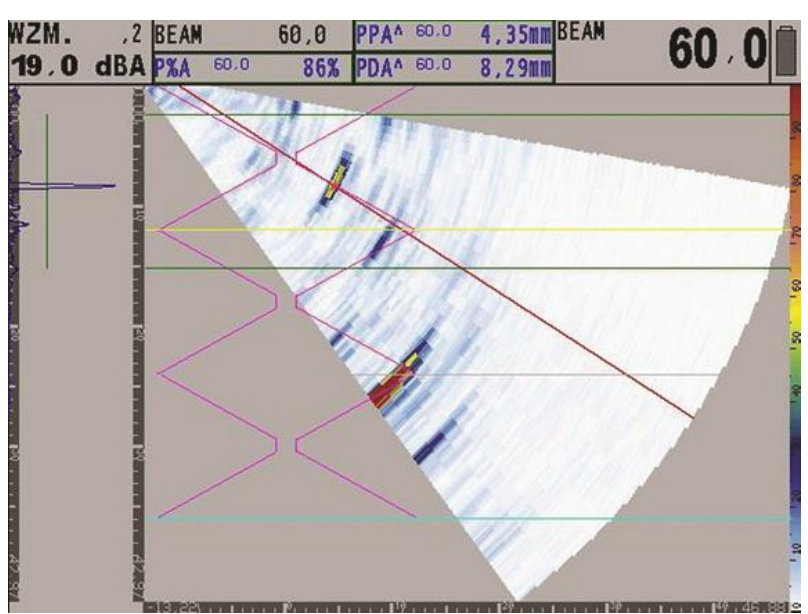

(a)

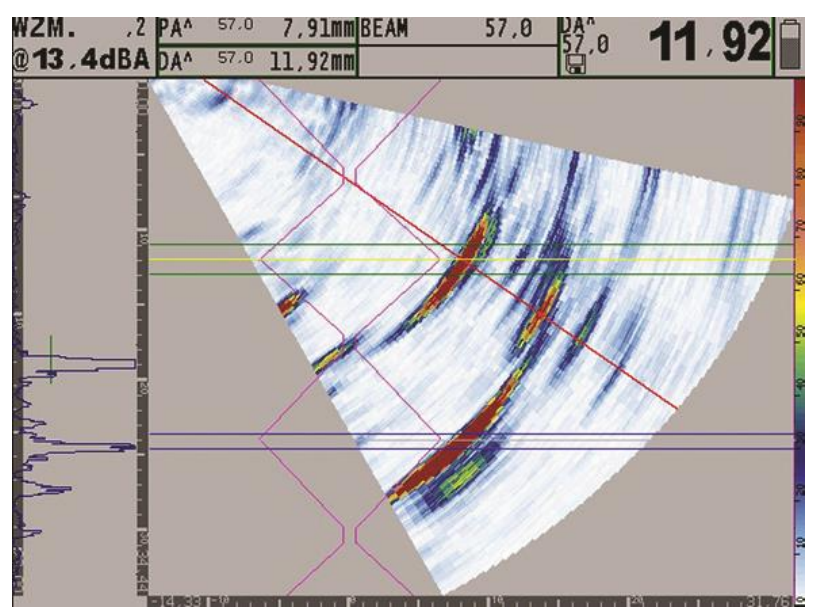

(b)

Fig. 6. Example results of UT, Phased Array: a) Specimen 1; b) Specimen 2 


\section{Static tensile tests}

After carrying out non-destructive tests and cutting the samples in accordance with the scheme (Fig. 2), destructive tests were started. The first was a static tensile test in which two samples from each joint were stretched.

For both specimens from the joint no. 1, the loss of sample consistency occurred in base material S460ML. A similar result was observed during stretching one of the samples of the other joint. The second sample from this joint broke in the HAZ and after the fusion line from the S460N steel side. The presence of non-compliance during non-destructive testing was detected here, which was confirmed during the tensile test. None of the obtained $R_{m}$ values of the S460ML material reached the value specified by the manufacturer of the sheet (Table II). Table IV presents the results of a static tensile test.

Table IV. Results of static tensile test

\begin{tabular}{cccccc}
\hline Joint No. & Sample No. & Cross-sectional area $\left[\mathbf{m m}^{2}\right]$ & $\begin{array}{c}\text { Force } \\
{[\mathbf{N}]}\end{array}$ & $\begin{array}{c}\mathbf{R}_{\mathrm{m}} \\
{[\mathrm{MPa}]}\end{array}$ & $\begin{array}{c}\text { Minimum value } \mathbf{R}_{\mathrm{m}} \\
\text { by PN-EN 10025:2007 }\end{array}$ \\
\hline \multirow{2}{*}{1} & 1 & 300 & 170000 & 575 & $540[\mathrm{~S} 460 \mathrm{ML}]$ \\
& 2 & 300 & 165000 & 559 & $540[\mathrm{~S} 460 \mathrm{ML}]$ \\
2 & 1 & 300 & 140000 & 467 & $520[\mathrm{~S} 460 \mathrm{~N}]$ \\
& 2 & 300 & 17200 & 573 & $540[\mathrm{~S} 460 \mathrm{ML}]$ \\
\hline
\end{tabular}

\section{Bending tests}

The bending test was carried out on a hydraulic press equipped with rollers and a $20 \mathrm{~mm}$ bending mandrel. The distance between the rolls was equal to the sum of two sheet thicknesses and the diameter of the rolls $(44 \mathrm{~mm})$. Four samples from each joint were tested. Two were bent from the face and two from the root. In the case of a welded sample with more heat input, compressed specimens from the root side and one compressed specimen from the face side cracked. All cracks occurred in HAZ of the S460N base material. During the test of the second joint, all samples were cracked in the HAZ of the S460N steel. The fractures of all samples were bright. Table $\mathrm{V}$ presents the results of the bending test.

Table V. Results of bending test

\begin{tabular}{ccc}
\hline Joint No. & Sample No. & Crack area \\
\hline \multirow{3}{*}{1} & 1 & HAZ S460N \\
& 2 & HAZ S460N \\
& 3 & HAZ S460N \\
& 4 & Lack \\
\hline \multirow{2}{*}{2} & 1 & HAZ S460N \\
& 2 & HAZ S460N \\
& 3 & HAZ S460N \\
& 4 & HAZ S460N \\
\hline
\end{tabular}

\section{Impact tests}

Four samples were taken from each joint, which were subjected to an impact test at $23{ }^{\circ} \mathrm{C}$, using the Charpy's hammer. Notch was made in each of the samples, with two samples from each joint having a notch in the weld's axis (1 and 2) and two in MR S460N just near HAZ (3 and 4). To determine the shape of the joint and the location of its characteristic areas, the samples were etched with $4 \%$ nital. The notch in each sample was V-shaped and was made at an angle of $45^{\circ}$, and its depth was $22 \mathrm{~mm}$. The width and height of the samples was $10 \mathrm{~mm}$. Completed research showed that samples welded with higher heat input (sample 1) required more impact energy, which translated into a higher impact strength for this joint. In the case of the second joint, one of the samples broke into two parts, while all the others remained in their entirety. A clear difference in crack location was observed for samples that had a notch in the base material. In the case of a joint welded with a higher amount of introduced heat, the crack occurred in the material S460N, while for a joint welded with a smaller heat input, the samples cracked in the HAZ. Figure 7 shows a view of some of the samples after the Charpy's hammer test. Table VI presents the results of the impact test. 


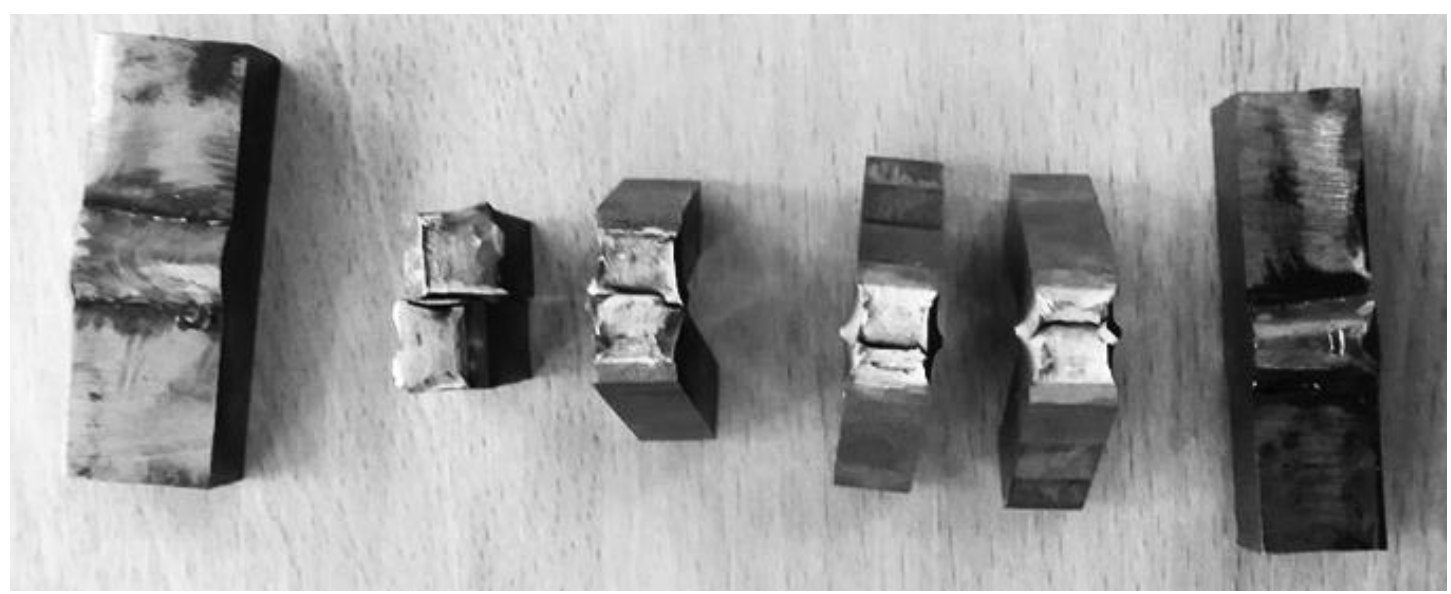

Fig. 7. The view of exemplary results of impact test (four middle specimen) and specimens for hardness measurements

Table VI. Results of impact test

\begin{tabular}{ccccc}
\hline Joint No. & Sample No. & Striking energy [J] & $\begin{array}{c}\text { Impact strength } \\
{\left[\mathbf{J} / \mathbf{c m}^{2}\right]}\end{array}$ & Crack area \\
\hline \multirow{3}{*}{1} & 1 & 65 & 81.25 & HAZ 460N \\
& 2 & 65 & 81.25 & Weld \\
& 3 & 114 & $>142.20$ & NM S460N \\
4 & 108 & $>135.00$ & NM 460N \\
\hline \multirow{2}{*}{2} & 11 & 50 & 62.50 & HAZ S460N \\
& 2 & 65 & 81.25 & HAZ 460N \\
& 3 & 75 & 93.75 & HAZ 460N \\
& 4 & 120 & $>150.00$ & Weld \\
\hline
\end{tabular}

${ }^{1}$ Sample fractured into two parts

\section{Hardness measurements}

One sample from each joint was tested in hardness measurements using the Vickers HV10 method. Samples were ground using water sandpaper and then etched with $4 \%$ nital to visualize joint areas. The samples were tested in accordance with the diagram presented in Figure 8, with three measurements made at each of the marked points at a short distance from each other. The results of the measurements are given in table VII.

Table VII. Results of Vickers HV10 hardness measurements

\begin{tabular}{cccccccccccc}
\hline $\begin{array}{c}\text { Distance from the face of the weld } \\
\text { [mm] }\end{array}$ & \multicolumn{3}{l}{ HAZ S460ML } & \multicolumn{3}{c}{ Weld } & \multicolumn{3}{c}{ HAZ S460N } \\
\hline & I & II & III & I & II & III & I & II & III \\
\hline & & \multicolumn{4}{c}{ Joint no. 1} \\
1 & 330 & 348 & 347 & 244 & 254 & 254 & 376 & 323 & 355 \\
3 & 342 & 358 & 319 & 236 & 242 & 245 & 379 & 334 & 345 \\
5 & 325 & 359 & 326 & 253 & 250 & 240 & 318 & 341 & 324 \\
7 & 327 & 348 & 339 & 248 & 245 & 246 & 325 & 347 & 344 \\
9 & 350 & 327 & 325 & 239 & 240 & 239 & 366 & 352 & 360 \\
11 & 355 & 376 & 370 & 230 & 235 & 237 & 357 & 376 & 376 \\
average & & 342 & & & 243 & & & 350 & \\
\hline & & & Joint no. 2 & & & & \\
3 & 332 & 340 & 341 & 239 & 250 & 250 & 379 & 358 & 349 \\
5 & 325 & 356 & 345 & 242 & 249 & 260 & 359 & 343 & 356 \\
7 & 352 & 348 & 338 & 249 & 250 & 257 & 363 & 350 & 350 \\
9 & 350 & 339 & 342 & 229 & 245 & 238 & 349 & 365 & 371 \\
11 & 340 & 333 & 351 & 238 & 237 & 244 & 352 & 359 & 372 \\
average & 346 & 335 & 339 & 260 & 249 & 257 & 357 & 377 & 364 \\
\hline
\end{tabular}




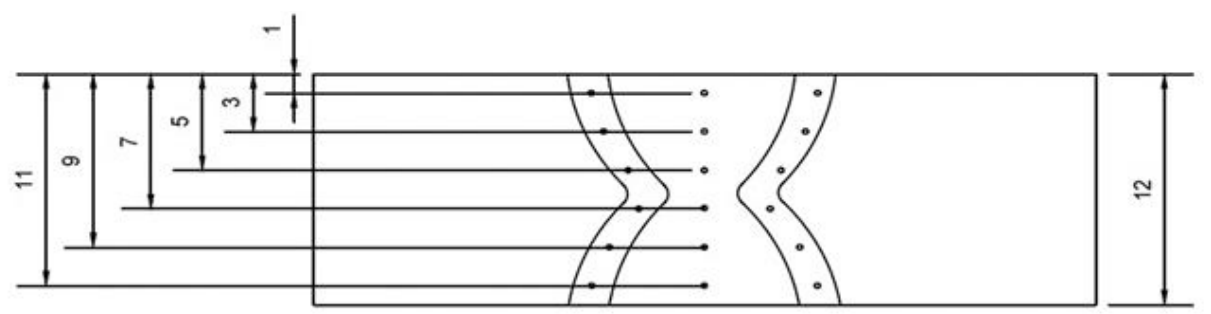

Fig. 8. Vickers HV10 hardness distribution points

\section{Discussion}

Performed tests showed that in the case of welding dissimilar S460ML and S460N steel butt joints, the value of heat input has a significant impact on the quality of the connection. During the implementation of non-destructive testing, at each stage, the joint made with lower heat input showed a greater number of welding imperfections. However, the defects were located in both joints in the HAZ of both materials. This confirms previous tests, which showed that they are characterized by limited (S460ML) and poor (S460N) weldability. This was confirmed during destructive tests, which also noted that the decrease in the heat input value during welding translated into a deterioration in the mechanical properties of the joints. The effect of welding with higher heat input was particularly noticed in the case of hardness measurements. They showed that the HAZ hardness of S460N steel significantly increased when the amount of heat introduced during welding was reduced, which can increase the susceptibility of this material to cold cracking.

All performed studies also confirmed that the use of S460N steel with a higher carbon equivalent value (Семis 0.464) than in S460ML (0.365) steel increases the number of welding imperfections, which confirms the results obtained in previous studies [25].

\section{Conclusions}

Completed research allowed to formulate the following conclusions:

1. The heat input value during welding significantly affects the quality of dissimilar joints made of highstrength low-alloy steel. Welding with higher heat input reduces the number of welding imperfections.

2. S460N steel with a higher carbon equivalent (0.464) than S460ML (0.365) has an increased tendency to generate welding imperfections.

3. Welding with higher heat input improves the mechanical properties of butt joints made of highstrength low-alloy steel.

4. Welding with higher heat input leads to lower hardness in the HAZ of high-strength low-alloy steel, which may decreases the susceptibility to cold cracking of S460ML and S460N steels.

Author Contributions: conceptualization J.T.; methodology J.T.; formal analysis J.T. and J.H.; investigation J.T. and J.H.; writing - original draft preparation J.T.; writing - review and editing J.T. and J.H.

Funding: This research received no external funding

Conflicts of Interest: The authors declare no conflict of interest.

\section{References}

[1] Qiang X., Bijlaard F., Kolstein H., Elevated-temperature mechanical properties of high strength structural steel S460N: Experimental study and recommendations for fire-resistance design. Fire Safety Journal, 2013, Vol. 55, 1521. http://dx.doi.org/10.1016/j.firesaf.2012.10.008

[2] Fydrych D., Rogalski G., Tomków J., Łabanowski J., Skłonność do tworzenia pęknięć zimnych złączy ze stali S420G2+M spawanej pod wodą metodą mokrą. Welding Technology Review, 2013, Vol. 85(10), 65-71. http://dx.doi.org/10.26628/wtr.v85i10.192

[3] Liu Z., Olivares R. O., Lei Y., Garcia C. I., Wang G., Microstructural characterization and recrystallization kinetics modeling of annealing cold-rolled vanadium microalloyed HSLA steels. Journal of Alloys and Compounds, 2016, Vol. 679, 293-301. https://doi.org/10.1016/j.jallcom.2016.04.057

[4] Dai H-L., Jiang H-J., Dai T., Xu W-L., Luo A-H., Investigarion on the influence of damage to springback of Ushape HSLA steel plates. Journal of Alloys and Compounds, 2017, Vol. 708, 575-586.

https://doi.org/10.1016/j.jallcom.2017.02.270 
[5] Górka J., Ozgowicz A., Matusek K., Robotic Spot Welding of DOCOL 1200M Steel. Welding Technology Review, 2019, Vol. 91(4), 33-38. https://doi.org/10.26628/wtr.v91i4.1007

[6] Tomków J., Janeczek A, Underwater in situ local heat treatment by additional stitches for improving the weldability of steel. Applied Sciences, 2020, Vol. 10(5), 1823. https://doi.org/10.3390/app10051823

[7] Sharma S. K., Maheshwari S., Arc characterization study for submerged arc welding of HSLA (API X80) steel. Journal of Mechanical Science and Technology, 2017, Vol. 31(3), 1383-1390. https://doi.org/10.1007/s12206-017-0238-6

[8] Mert T., Tümer M., Kerimak Z. M., Investigations on mechanical strength and microstructure of multi-pass welded S690QL HSLA steel using MAG and FCAW. Practical Metallography, 2019, Vol. 56(10), 634-654. https://doi.org/10.3139/147.110578

[9] Zhang S., Sun J., Zhu M., Zhang L., Nie P., Li Z., Fiber laser welding of HSLA steel by autogenous laser welding and autogenous laser welding with cold wire methods. Journal of Materials Processing Technology, 2020, Vol 275, 116353. https://doi.org/10.1016/j.jmatprotec.2019.116353

[10] Šebestová H., Horník P., Mrňa L., Jambor M., Horník V., Pokorný P., Hutař P., Ambrož O., Doležal P., Fatigue properties of laser and hybrid laser-TIG welds of thermos-mechanically rolled steels. Materials Science and Engineering: A, 2020, Vol. 772, 138780. https://doi.org/10.1016/j.msea.2019.138780

[11] Skowrońska B., Chmielewski T., Pachla W., Kulczyk M., Skiba J., Presz W., Friction weldability of UFG 316L stainless steel, Archives of Metallurgy and Materials, 2019, Vol. 64(3), 1051-1058.

https://doi.org/10.24425/amm.2019.129494

[12] Kannengiesser T., Boellinghaus T., Cold cracking tests - an overview of present technologies and applications. Welding in the World, 2013, Vol. 57, 3-37. https://doi.org/10.1007/s40194-012-0001-7

[13] Pandey C., Saini N., Mahapatra M. M., Kumar P., Hydrogen induced cold cracking of creep resistance ferritic P91 steel for different diffusible hydrogen levels in deposited metal. International Journal of Hydrogen Energy, 2016, Vol. 41(39), 17695-17712. https://doi.org/10.1016/j.ijhydene.2016.07.202

[14] Wang J., Lu S., Li Y., Hu Q., Rong L., Li D., Cold cracking sensitivity of a newly developed 9Cr2WVTa steel. Journal of Materials Engineering and Performance, 2017, Vol. 26, 258-267. https://doi.org/10.1007/s11665-016-2432-6

[15] Tomków J., Fydrych D., Rogalski G., Łabanowski J., Effect of the welding environment and storage rime of electrodes on the diffusible hydrogen content in deposited metal. Revista de Metalurgia, 2019, Vol. 55(10), E140. https://doi.org/10.3989/revmetalm.140

[16] Tomków J., Fydrych D., Rogalski G., Role of bead sequence in underwater welding. Materials, 2019, Vol. 12(20), 3372. https://doi.org/10.3390/ma12203372

[17] Kempen K., Vrancken B., Buls S., Thijs L., Humbeeck J.V., Kruth J.P., Selective laser melting of crack-free high density M2 high speed steel parts by baseplate preheating. Journal of Manufacturing Science and Engineering, 2014, Vol. 136(6), 061026. https://doi.org/10.1115/1.4028513

[18] Hu L. H., Huang J., Li Z. G., Wu Y. X., Effects of preheating temperature on cold cracks, microstructures and properties of high power laser hybrid welded 10Ni3CrMoV steel. Materials\&Design, 2011, Vol. 32(4), 1931-1939. https://doi.org/10.1016/j.matdes.2010.12.007

[19] Zhang Y., Zhang H., Li J., Liu W., Effect of heat input on microstructure and toughness of coarse grain heat affected zone in $\mathrm{Nb}$ microalloyed HSLA steels. Journal of Iron and Steel Research International, 2009, Vol. 16, 73-80. https://doi.org/10.1016/S1006-706X(10)60014-3

[20] Lahtinen T., Vilaça P., Peura P., Mehtonen S., MAG welding tests of modern high strength steels with minimum yield strength of $700 \mathrm{MPa}$. Applied Science, 2019, Vol. 9(5), 1031. https://doi.org/10.3390/app9051031

[21] Górka J., Kotarska A., MAG welding of 960QL quenched and tempered steel. IOP Conference Series: Materials Science and Engineering, 2019. Vol. 591, 012017. https://doi.org/10.1088/1757-899X/591/1/012017

[22] Min D., Hin-hua T., Feng-qui L., Shun Y., Welding of quenched and tempered steeld with high-spin arc narrow gap MAG system. The International Journal of Advanced Manufacturing Technology, 2011, Vol. 55(5-8), 527-533. https://doi.org/10.1007/s00170-010-3052-1

[23] Tomków J., Łabanowski J., Fydrych D., Rogalski G., Cold cracking of S460N steel in water environment. Polish Maritime Research, 2018, Vol. 25, 131-136. https://doi.org/10.2478/pomr-2018-0104

[24] Tomków J., Rogalski G., Fydrych D., Łabanowski J., Advantages of the application of the temper bead welding technique during wet welding. Materials, 2019, Vol. 12(6), 915. https://doi.org/10.3390/ma12060915

[25] Tomków J., Tomków M., The influence of the carbon equivalent on the weldability of high-strength low-alloy steel in the water environment. Welding Technology Review, 2019, Vol. 91(5), 43-49.

https://doi.org/10.26628/wtr.v91i5.1001

(C) 2020 by the authors. Submitted for possible open access publication under the terms and conditions of the Creative Commons Attribution (CC BY) license (http://creativecommons.org/licenses/by/4.0/). 